\title{
HOME RANGE OF THE TROPIDURID LIZARD Liolaemus lutzae: SEXUAL AND BODY SIZE DIFFERENCES
}

\author{
ROCHA, C. F. D. \\ Setor de Ecologia, Instituto de Biologia, Universidade do Estado do Rio de Janeiro, \\ Rua São Francisco Xavier, 524, Maracanã, CEP 20550-019, Rio de Janeiro, RJ, Brazil \\ Correspondence to: Carlos Frederico Duarte Rocha, Setor de Ecologia, Instituto de Biologia, \\ Universidade do Estado do Rio de Janeiro, Rua São Francisco Xavier, 524, Maracanã, CEP 20550-019, \\ Rio de Janeiro, RJ, Brazil, e-mail: cfdrocha@uerj.br \\ Received July 10, 1997 - Accepted June 06, 1998 - Distributed February 23, 1999
}

(With 1 figure)

\begin{abstract}
The home range of the Tropidurid lizard Liolaemus lutzae, an endemic species of the costal sand dune habitats of Rio de Janeiro State, was studied in the beach habitat of Barra de Maricá restinga, Maricá County. Home ranges were studied using a mark-recapture technique in a delimited area at the beach habitat. I considered for estimates and analysis the home ranges of those lizards with a minimum of four positions. The size of L. lutzae home ranges varied according to the segment of the population. The mean home range size of adult males $\left(x=59.8 \pm 33.7 \mathrm{~m}^{2}\right)$ was significantly larger than that of adult females $\left(x=22.3 \pm 16.1 \mathrm{~m}^{2}\right)$. Juvenile mean home range size was significantly smaller than that of adult males, but did not differ from that of adult females $(t=1.058 ; \mathrm{p}=0.149)$. The overlap between male home ranges was usually low (3.6\%), being in general only peripheral. Conversely, there was a considerable overlap between home ranges of adult females with those of adult males, the home range areas of two or three females being enclosed in the home range of one adult male. The small overlap between home ranges of adult males suggested mutual exclusion. The observed between-sex differences in the size of L. lutzae home range may be explained by the sexual dimorphism in body size in this species, and by the need of adult males to establish larger areas so as to include many females in their areas, during the reproductive season. The differences in home range along ontogeny probably result from differences in body size of the different segments of the population, due to trophic differences (carnivory and herbivory levels), and the dispersal of young after birth. Because L. lutzae is omnivorous, but primarily herbivorous when adult, and due to its sit-andwait foraging behavior (mainly on arthropods), it does not need to move around over large areas to find food, which in turn reduces the area necessary for it to live.
\end{abstract}

Key words: home range, endemism, territory, lizard, restinga.

\section{RESUMO}

\section{Área de vida do lagarto tropidurídeo Liolaemus lutzae: diferenças sexuais e no tamanho corporal}

A área de vida do lagarto tropidurídeo Liolaemus lutzae, espécie endêmica do Estado do Rio de Janeiro, foi estudada no hábitat de praia da restinga da Barra de Maricá, Município de Maricá. A área de vida foi estudada através de marcação e recapturas sucessivas em uma área demarcada para o estudo. Foram consideradas, para as estimativas e para as análises, apenas as áreas de vida de lagartos para os quais foram obtidas quatro ou mais posições, de forma a preservar estimativas mais acuradas. Os dados mostraram que entre os adultos o tamanho médio da área de vida dos machos $\left(59,8 \pm 33,7 \mathrm{~m}^{2}\right)$ foi superior a das fêmeas $\left(22,3 \pm 16,1 \mathrm{~m}^{2}\right)$. A área de vida de um macho pode incluir duas a três fêmeas. A área de vida dos jovens não diferiu significativamente daquela das fêmeas, mas foi inferior à dos machos adultos. Provavelmente, este padrão resulta das diferenças no tamanho corporal entre os diferentes segmentos da população, das diferenças tróficas (níveis de carnivoria e herbivoria) e da dispersão dos jovens após o nascimento. A baixa sobreposição na área de vida entre machos adultos $(3,6 \%)$ 
pode indicar exclusão mútua, enquanto a baixa sobreposição entre as áreas de fêmeas $(3,9 \%)$ parece refletir o menor tamanho de suas áreas e o seu comportamento residente. Devido ao fato de que $L$. lutzae é uma espécie onívora, mas primariamente herbívora quando adulta, e devido ao seu comportamento de forrageador sedentário em relação aos artrópodos, os indivíduos da espécie não necessitam movimentar-se por extensas áreas para encontrar alimento, o que resulta em uma relativa restrição em termos do tamanho da área de que cada indivíduo precisa para viver.

Palavras-chave: área de vida, endemismo, território, lagarto, restinga

\section{INTRODUCTION}

The home range, which is the total area in which an individual of a particular species lives and wanders when active, and where it finds food, mates and shelter (Rose, 1982), varies considerably among lizard species, affected by some ecological factors (Turner et al., 1969). Some studies have shown that the size of a lizard's home range may be strongly influenced by the size of the animal (Turner et al., 1969; Christian \& Waldschmidt, 1984; Van Sluys, 1997) or by its trophic level (Cristian \& Waldschmidt, 1984).

Liolaemus lutzae is a Tropidurid lizard endemic to the coastal sand plains ("restingas") of Rio de Janeiro State in southeastern Brazil (Vanzolini \& Ab'Saber, 1968) where it is restricted to the beach habitats (Rocha, 1991). This lizard has a marked sexual dimorphism in size, males being larger (and having larger heads) than females (Rocha, 1996a). When adult, males usually attain a snout-vent length (SVL) of 75 to $81 \mathrm{~mm}$ whereas adult females attain 60 to $64 \mathrm{~mm} \mathrm{SVL}$ (Rocha, 1992a). Considering that body size is an important factor affecting lizard home range size I hypothetized that the differences in body size between males and females of L. lutzae would result in differences in home range size between sexes, and adult male home ranges would be larger than those of adult females. In addition, because there is consistent evidence for territorial behavior of adult males of L. lutzae (see Rocha 1996a), one would expect a relatively small overlap in home range areas within adult males. This study was performed to analyse L. lutzae home range, specificaly adressing the following questions: I) What is the average home range size of L. lutzae? II) Are there sexual differences in home range sizes? III) Do these differences occur between juveniles and adults? IV) Is there overlap between home range areas of adult males? V) To what extent do home ranges of adult females overla? VI) How many females are usually associated to individual male home ranges?

\section{MATERIAL AND METHODS}

\section{Study area}

This study was carried out in the Restinga da Barra de Maricá (22 $\left.57^{\prime} \mathrm{S}, 43^{\circ} 50^{\prime} \mathrm{W}\right)$ which is located approximately $38 \mathrm{Km}$ east from Rio de Janeiro City, Rio de Janeiro State, Southeastern Brazil. The climate of Barra de Maricá is wet and warm with mean annual temperature of $22-24^{\circ} \mathrm{C}$ (Nimer, 1972, 1979) and a marked seasonality in rainfall (Rocha, 1992a). Most rain falls from December to March whereas a period of relative drought occurs from May to Sepetember. Annual rainfall in the area varies from 1000 to $1350 \mathrm{~mm}$ (Nimer, 1972, 1979; Rocha, 1992a).

In Barra de Maricá, L. lutzae is restricted to the beach habitat which is an open sand dune area covered by herbaceous vegetation. For detailed description of the habitat of L. lutzae see Rocha (1991). This lizard species was recently included in the Brazilian checklist of the fauna threatened with extinction in which it was considered a species insufficiently known, and believed to be threatened (Bernardes et al., 1990).

\section{Collecting methods}

In the beach habitat I delimited an area of approximately 3.5 ha $(70 \mathrm{~m}$ wide $\mathrm{x} 500 \mathrm{~m}$ extension) in which I performed a mark-recapture program. To make it easier to locate lizard position inside the area I placed wood stakes $(40 \mathrm{~cm}$ height) each $10 \mathrm{~m}$ interval. The wood stakes were inserted in the sandy soil with the upper $25 \mathrm{~cm}$ sticking out of sand. I made regular field trips fortnightly from December 1986 through April 1987. During each excursion all of the area was systematically searched for L. lutzae. When a lizard was found an attempt was made to capture it by hand. The lizard's original positon was located and 
recorded according to a cartesian axis system, in which the " $y$ " axis was the distance (in $m$ ) from the lizard's original position to the initial vegetation colonization line (beach width) and the "x" axis the distance from this point to the established "zero" of beach extension. In addition, the SVL of the captured lizards was measured using a Vernier caliper (to the nearest $0,1 \mathrm{~mm}$ ) and the weight (in g) using a Pesola spring balance (to the nearest 0.2 g). Lizard sex was recorded, the individuals marked using toe-clipping (Woodbury, 1956) and released at the exact place where they were first seen.

The recognition of $L$. lutzae sex is relatively easy in the field because males are larger, have wider heads, have conspicuous orange pre-anal pores (easy to see even in hatchlings) and because the sexes differ markedly in the shape of the cloaca opening (see Rocha, 1996a).

To estimate $L$. lutzae home range I used the Convex Polygon Method (Hayne, 1949). By this method, the points that represent the several capture positions of an individual are plotted, the most external points being linked in order to form a polygon. The area of the polygon represents the area used by that individual (i.e. its home range) (Hayne, 1949). Although there are some different methods for estimating home ranges (e. g. Davis, 1953; Jorgensen \& Tanner, 1963; Rose, 1982; Anderson, 1982; Christian and Waldsmidt, 1984), the Convex Polygon Method has been indicated as the most appropriate for vertebrates (Rose, 1982; Waldschmidt, 1979).

In this study I just considered for estimates and analysis the home ranges of those lizards for whom I obtained four or more positions, which is recommended for more accurate estimates (Rose, 1982). Also, to avoid seasonal variation in home range sizes, which may occur in many species as a result of seasonal variation in food resource in the habitat (McNab, 1963; Sherfy \& Chapman, 1980; Bergallo, 1990), I considered home range estimates only during the wet season (DecemberApril).

Differences between mean home range size (in $\mathrm{m}^{2}$ ) of adult males and females and between juveniles of both sexes were tested using Student's t-test (Zar, 1984). The minimum size at maturity for females $(\mathrm{SVL}=51.5 \mathrm{~mm})$ and males $(\mathrm{SVL}=$ $61.1 \mathrm{~mm}$ ) were those reported in the reproductive study of Rocha (1992a) for the same L. lutzae population of the present study.

\section{RESULTS}

Field data on mark-recapture indicated that adult $L$. lutzae are markedly resident in a particular area of the beach habitat. Even after successive months and, from one year to another (C.F.D. Rocha, pers. obs.), individuals tended to remain in the same area and, in most cases, they were found only one to a few meters from their original position. Conversely, many juveniles were recaptured at distances of $40 \mathrm{~m}$ up to $50 \mathrm{~m}$ from their original positions.

The size of $L$. lutzae home range varied according to the segment of the population. The mean home range size of adult males $(\mathrm{x}=59.8$ $\pm 33.7 \mathrm{~m}^{2} ; \mathrm{N}=10$ ) was significantly larger than that of adult females $\left(\mathrm{x}=22.3 \pm 16.1 \mathrm{~m}^{2} ; \mathrm{N}=11\right.$ $(\mathrm{t}-$ test, $\mathrm{t}=3.30 ; \mathrm{df}=19 ; \mathrm{p}=0.001$ (Fig. 1). Within juveniles, there was no significant difference in the mean size of home range between sexes $\left(\mathrm{x}_{\text {males }}=\right.$ $31.9 \pm 21.9 \mathrm{~m}^{2} ; \mathrm{N}=10 ; \mathrm{x}_{\text {females }}=29.1+24.0 \mathrm{~m}^{2}$; $\mathrm{N}=13 ; \mathrm{t}=0.296 ; \mathrm{df}=21 ; \mathrm{p}=0.385)$. Juvenile home range size was significantly smaller than that of adult males $(\mathrm{t}=2.950 ; \mathrm{df}=31 ; \mathrm{p}=0.003)$, but did not differ statistically from that of adult females $(\mathrm{t}=1.058 ; \mathrm{df}=32 ; \mathrm{p}=0.149)$.

The overlap between male home ranges was usually low (3.6\%) being in general only peripheral (Fig. 1a e b). Conversely, there was a considerable overlap between the home range of adult females with those of adult males (Fig. 1a e b). In some cases, the home range area of two or three females were enclosed in the home range of an adult male (Fig. 1a e b).

Within adult females, the overlap between their home ranges was also considerably low (3.9\%) (Fig. 1a e b). The home range of juvenile males and females overlapped considerably with those of both adult males and adult females.

In many occasions during the study juveniles and adults of both sexes were found sharing the same shelter (i.e. under the same debris). However, adult females were found in this situation only with sub-adults.

\section{DISCUSSION}

In Liolaemus lutzae, home range size of adult males averaged 2.7 times larger than that of adult females. Adult males of L. lutzae are considerably larger than adult females (Rocha, 1996a). 

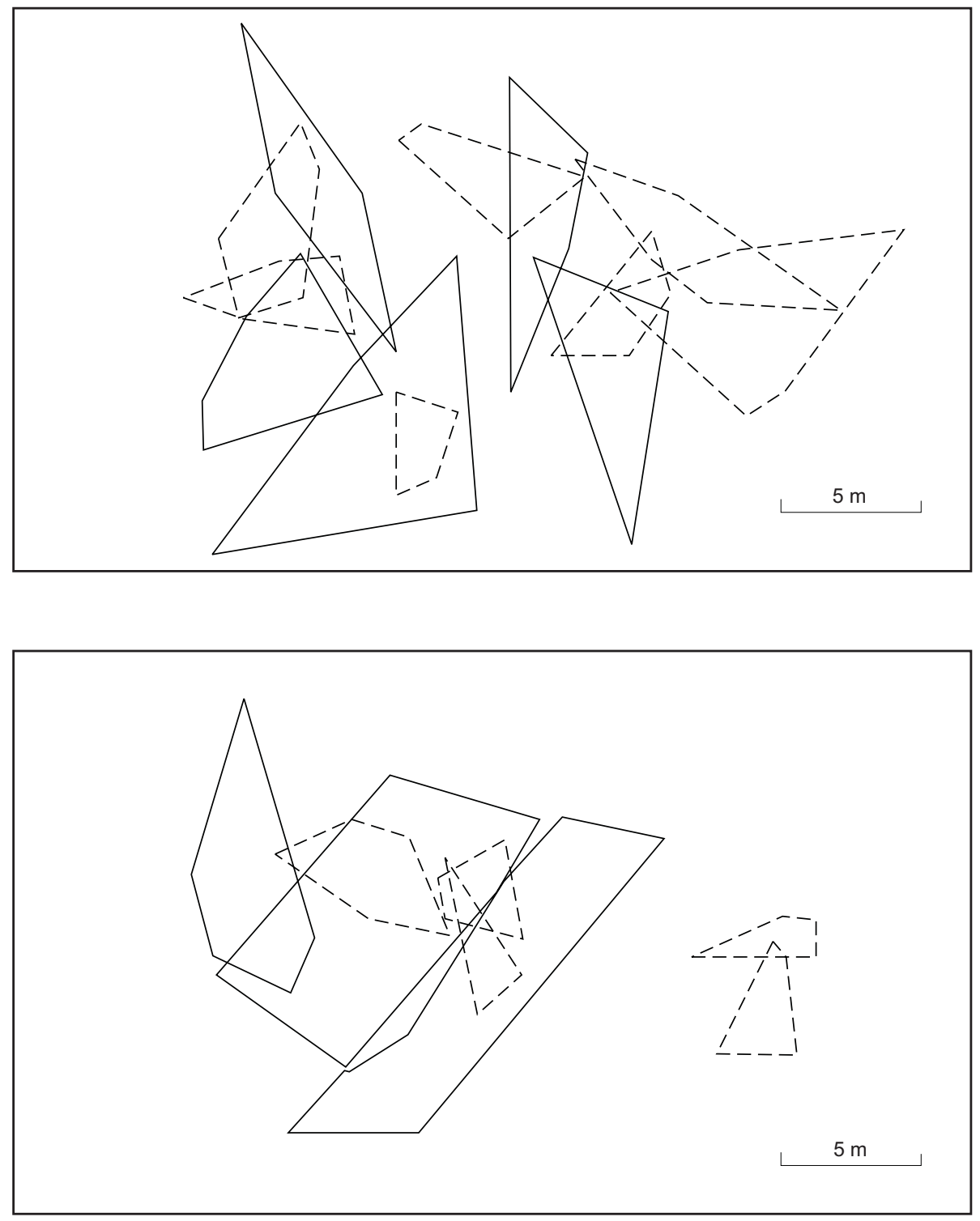

Fig. 1 - Individual home ranges of adult males (full lines) and adult females (dashed lines) of Liolaemus lutzae in two portions ( $a$ and $b$ ) of the study area in the beach habitat of Barra de Maricá restinga in Rio de Janeiro State. Only home ranges of individuals with at least four positions were included.

The observed differences in the size of $L$. lutzae home range between the sexes may be explained by the sexual dimorphism in size in this species (Rocha, 1995) and by the need of adult males to establish larger areas so as to include many females in their areas, during the reproductive season. Males of many lizard species have home ranges twice as large as females and this is an important factor during the reproductive period (Rose, 1982;
Stamps, 1983; Van Sluys, 1997). Conversely, the size of the home range of $L$. lutzae juveniles was significantly smaller than that of adult males but did not differ statistically from that of adult females. Although differences in body size among juveniles and adults may in part explain the differences found in home range size, probably there are also other important factors. One possible additional factor is the ontogenetic shift in diet of 
L. lutzae, in which juveniles are essentially carnivores whereas adults are predominantly herbivores (Rocha, 1989, 1992b, 1998).

The trophic level has been demonstrated to be an important factor influencing home range size in birds (Armstrong, 1965; Schoener, 1968), mammals (Mcnab, 1963; Milton \& May, 1976; Harestad \& Bunnel, 1979; Lindstedt et al., 1986; Bergallo, 1990) and lizards (Christian \& Waldschmidt, 1984). Similarly, as found in other animal groups, insectivore/carnivore lizards have larger home ranges than herbivores (Christian \& Waldschmidt, 1984; Saint-Girons \& Saint-Girons, 1959), because they need larger areas to search for and to find their preys. Juveniles of $L$. lutzae are mainly carnivores feeding essentially on terrestrial arthropods (Rocha, 1989, $1992 b, 1998)$ in a habitat with relatively low arthropod availability (Rocha, 1996b).

Having such a diet, juveniles probably need to move over larger areas to get adequate food provision, compared to adult females which, being primarily herbivores (and consequently having more immobile and predictable food resources), can be more sedentary. Moreover, juveniles of $L$. lutzae initiate dispersion just after hatching, in order to establish their own home ranges, which probably results in an increase in their movement rate. The comparatively long recapture distances $(40-50 \mathrm{~m})$ from their original position found for juveniles as compared to those for adults, reinforces the idea of higher movement rate of juveniles which is probably due to their dispersion. The larger home range size of adult males, as compared to that of juveniles probably results from, at least, two factors: the former need larger areas to include as many females as possible and have larger body sizes.

The data indicate that there was small overlap among adult male home ranges $(3.6 \%)$, and that the area of males usually included the areas of two or three females. The advantage for males of having larger home ranges seems obvious, inasmuch as frequency of males mating depends on the number of females associated to each male home range or territory (Rose, 1982; Stamps, 1983). The small overlap between home ranges of adult males suggests mutual exclusion. The exclusion constitutes indirect evidence of territoriality and is indicative that, for L. lutzae, home range size is coincident with that of its territory. The small overlap in the home range of individuals of a particular lizard species has been interpreted as being characteristic of territorial species (Rose, 1982; Ruby, 1976). Rocha (1996a) observed that the frequency of bite scars in adult males as a result of their agonistic interactions, increased considerably during the reproductive season, suggesting that sexual differences in body size, especially in head size would result from the intrasexual selection acting within males. The small overlap in male home ranges found in the present study, supports this idea. Differences in the amount of overlap that may occur among male home ranges of a particular species has been considered as indicative of hierarchy within males of the population (Rose, 1982; Ruby, 1976). However, there is no evidence of hierarchical behavior in females of lizards and the usual small overlap between their home ranges have been suggested as a result of the low frequency of encounters between females which in turn results from their smaller home ranges (Rose, 1982).

The sizes of male and female L. lutzae home ranges found in the present study, in general agrees with those predicted by Christian \& Waldschmidt (1984) for lizards of this size and trophic level. Because L. lutzae is omnivorous, but primarily herbivorous when adult (Rocha, 1989; 1996b), and due to its sit-and-wait foraging behavior foraging on arthropods (Rocha, 1996b), it does not need to move around over large areas to find food, which in turn reduces the area necessary for it to live.

Acknowledgements - This study is a portion of the results of the "Programa de Ecologia, Conservação e Manejo de Ecossistemas do Sudeste Brasileiro" and of the Southeastern Brazilian Vertebrate Ecology Project (Laboratory of Vertebrate Ecology), both of the Setor de Ecologia, Instituto de Biologia, Universidade do Estado do Rio de Janeiro and was made as part of the results of the Sand dune Reptiles of East Brazil Project which was supported by grants (numbers 402266/84; 403787/91-2; 300819/94-3 and 400115/97-2) of the Conselho Nacional do Desenvolvimento Científico e Tecnológico (CNPq) to the author. I am indebted to many friends that on different occasions assisted me in the field work, but particularly H. G. Bergallo, M. Van Sluys, P. R. Moutinho, C. B. A. Ramos and R. F. Fialho. I am specially grateful to A. S. Abe who gave important suggestions along the study and made many facilities available. Augusto S. Abe, I. Sazima, C. B. Haddad, M. T. U. Rodrigues and W. Rodrigues gave helpful suggestions on a former version of this manuscript and M. Van Sluys and D. Vrcibradic for latter review. I thank D. Vrcibradic and P. F. Teixeira-Filho for laboratorial assistantship. M. C. S. Souza kindly typed the manuscript. Universidade do Estado do Rio de Janeiro gave travel support in many occasions. 


\section{REFERENCES}

ANDERSON, D. J., 1982, The home range: a new non-parametric estimation technique. Ecology, 63: 103-112.

ARMSTRONG, J. T., 1965, Breeding home range in the night hawk and birds; its evolutionary and ecological significance. Ecology, 46: 619-629.

BERGALLO, H. G., 1990, Fatores determinantes do tamanho da área de vida em mamíferos. Ciência e Cultura, 42 (12): 1067-1072.

BERNARDES, A. T., MACHADO, A. B. M., \& RYLANDS, A. B., 1990, Brazilian fauna threatened with extinction. Fundação Biodiversitas para a Conservação da Diversidade Biológica.

CHRISTIAN, K. \& WALDSCHMIDT, S., 1984, The relationship between lizard home range and body size: a reanalysis of the data. Herpetologica, 40: 68-75.

DAVIS, D. E., 1953, Analysis of home range from recapture data. J. Mammal., 34: 352-358.

HARESTAD, A. S. \& BUNNEL, F. L., 1979, Home range and body weight - a reavaluation. Ecology, 60: 389-402.

HAYNE, D. W., 1949, Calculation of the home range. $J$. Mammal., 30: 1-18.

JORGENSEN, C. D. \& TANNER, W. W., 1963, The applications of the density probability function to determine the home ranges of Uta stansburiana stansburiana and Cnemidophorus tigris. Herpetologica, 19: 104-115.

LINDSTEDT, S. L., MILLER, B. J. \& BUSKIRK, S. W., 1986, Home range, time and body size in mammals. Ecology, 67: 413-418.

McNAB, B. K., 1963, Bioenergetics and the determination of home range size. Amer. Natur., 97: 133-140.

MILTON, K. \& MAY, M. L., 1976, Body weight, diet and home range area in Primates. Nature, 259: 459-462.

NIMER, E., 1972, Climatologia da região sudeste do Brasil Introdução à climatologia dinâmica - Subsídios à geografia regional do Brasil. Rev. Bras. Geog., 34: 3-48.

NIMER, E., 1979, Climatologia do Brasil. IBGE, Rio de Janeiro, 422p.

ROCHA, C. F. D., 1989, Diet of a tropical lizard (Liolaemus lutzae) of Southeastern Brazil. J. Herpetol., 23: 292-294.

ROCHA, C. F. D., 1991, Composição do hábitat e uso do espaço por Liolaemus lutzae (Sauria: Tropiduridae) em uma área de restinga. Rev. Bras. Biol., 51: 671-678.

ROCHA, C. F. D., 1992a, Reproductive and fat body cycles of the tropical sand lizard (Liolaemus lutzae) of Southeastern Brazil. J. Herpetol., 26: 17-23.

ROCHA, C.F.D., 1992b, Ecologia e comportamento de Liolaemus lutzae (Sauria: Tropiduridae) em uma área de restinga do Sudeste do Brasil. Tese de Doutorado, Departamento de Zoologia, Instituto de Biologia, Universidade Estadual de Campinas, Campinas, São Paulo, 176p.
ROCHA, C. F. D., 1995, Growth of the tropical sand lizard Liolaemus lutzae in Southeastern Brazil. Amphibia-Reptilia, 16: 257-264.

ROCHA, C. F. D., 1996a, Sexual dimorphism in the sand lizard Liolaemus lutzae of Southeastern Brazil. In: J.E. Péfaur (ed.), Herpetol Neotropical, pp. 131-141, Actas II Congr. Latinoam. Herp., Vol. II, Univ. Los Andes, Mérida, Venezuela.

ROCHA, C. F. D., 1996b, Seasonal shift in lizard diet: the seasonality in food resources affecting the diet of Liolaemus lutzae (Tropiduridae). Ciência e Cultura, 48 (4): 264-269.

ROCHA, C. F. D., 1998, Ontogenetic shift in the rate of plant consumption in a tropical lizard (Liolaemus lutzae). J. Herpetol., 32(2): 274-279.

ROSE, B., 1982, Lizard home ranges: methodology and functions. J. Herpetol., 16: 253-269.

RUBY, D. E., 1976, The behavioral ecology of the viviparous lizard Sceloporus jarrovi. Ph.D. thesis, University of Michigan, 214p.

SCHOENER, T. W., 1968, Sizes of feeding territories among birds. Ecology, 49: 123-141.

SAINT-GIRONS, H. \& SAINT-GIRONS, M. C., 1959, Espace vital, domaine territoire chez les vertebrés terrestres (reptiles et mammiferes). Mammalia, 23: 448-476.

SHERFY, F. C. \& CHAPMAN, J. A., 1980, Seasonal home range and habitat utilization of raccoons in Maryland. Carnivores, 3: 8-18.

STAMPS, J. A., 1983, Sexual selection, sexual dimorphism and territoriality in lizards. In: R.B. Huey, E. R. Pianka \& T. W. Schoener (eds.) Lizard Ecology: Studies on a model organism, Harvard University Press, Cambridge, 501p.

TURNER, F. B., JENNRICH, R. I. \& WEINTRAUB, J. D., 1969, Home ranges and body sizes of lizards. Ecology, 50: 1076-1081.

VAN SLUYS, 1997, Home range of the saxicolous lizard Tropidurus itambere in Southeastern Brazil. Copeia, 1997 (3): 623-628.

VANZOLINI, P. E. \& AB'SABER, A., 1968, Divergence rate in South American lizards of the genus Liolaemus (Sauria: Iguanidae). Pap. Avuls. Zool., São Paulo, 21: 205-208.

WOODBURY, A. M., 1956, Uses of marking animals: marking amphibians and Reptiles. Ecology, 37: 670-674.

WALDSCHMIDT, S. R., 1979, The effect of statistically based models on home range size estimate in Uta stansburiana. Am. Midl. Natur., 101: 236-240.

ZAR, J. H., 1984, Biostatistical analysis. PrenticeHall Inc., Englewood Cliffs, 718p. 